\title{
MENGUKUR WAKTU BONGKAR MUAT TRUCKING GUDANG MENGGUNAKAN AKSES KONTROL CARD RIDER
}

\author{
Agus Wiranto S.T., M.Kom. ${ }^{\text {I) }}$ \\ Jurusan Teknik Informatika, Fakultas Teknik, Universitas Pamulang \\ E-mail :awiranto339@gmail.com ${ }^{l}$
}

\begin{abstract}
Motivated by warehousing which is closely related to distribution, but sometimes it doesn't get serious intention. Even though in this distribution there is often a waste of costs, both in the cost of renting warehouses, transportation or loading and unloading costs, even if there is a delay in distribution and cargo loading will reduce the quality of the goods and hinder production, for example in food raw materials and processed goods. These goods have a monetary value as well as space for goods, for which the speed of distribution is greatly compromised. The objectives and stages of the research method are to analyze the arrival of distribution vehicles when queuing for arrival until loading and unloading is complete in the warehouse of a company that produces liquid sugar (Glucose), with the stage of the field analysis research method and installing a loading timer device that is directly connected to the system on the computer by using program, so that the output of the research report can improve loading and unloading performance with a predetermined time target
\end{abstract}

\begin{tabular}{l}
\hline Article History \\
\hline Received 2020-09-25 \\
Revised 2020-10-07 \\
Accepted 2020-11-04 \\
\hline
\end{tabular}

\section{Key words}

Gudang, Bongkar muat, Kinerja, Fingersport

\begin{abstract}
ABSTRAK
Dilatarbelakangi oleh Pergudangan yang erat sekali terkaitanya dengan distribusi, tetapi kadang kala sering kurang mendapatkan perhatian serius. Padahal di dalam distribusi ini sering terjadi pemborosan biaya baik di dalam ongkos sewa gudang, pengangkutan ataupun ongkos bongkar muat barang, bahkan bila terjadi keterlambatann distribusi dan bonkar muat barang akan menurunkan kualitas barang tersebut dan menghambat produksi, contohnya pada barang-barang bahan baku makanan dan olahan. Barang-barang itu mempunyai nilai uang begitu pula ruang tempat barang, untuk itu kecepatan distribusi sangat diburuhkan. Adapun tujuan dan tahapan metode penelitian adalah melakukan analisa kedatangan kendaraan distribusi saat antri kedatangan hingga bongkar muat selesai digudang sebuah perusahaan yang memproduksi gula cair(Glucose), dengan tahapan metode penelitian analisa lapangan dan memasangkan alat penghitng waktu loding yang langsung terhubung dengan sistem di komputer dengan mengunakan progra, sehingga dengan luaran laporan hasil penelitian dapat meningkatkan kinerja bongkar muat dengan target waktu yang telah ditentukan.
\end{abstract}

\section{PENDAHULUAN}

Didasari oleh Pergudangan yang erat sekali terkaitanya dengan distribusi, tetapi kadang kala sering kurang mendapatkan perhatian serius. Padahal di dalam distribusi ini sering terjadi pemborosan biaya baik di dalam ongkos sewa gudang, pengangkutan ataupun ongkos bongkar muat barang, bahkan bila terjadi keterlambatann distribusi dan bonkar muat barang akan menurunkan kualitas barang tersebut dan menghambat produksi, Six Big Losses adalah sebuah istilah ukuran untuk mengidentifikasi waktu rencana produksi yang berkaitan dengan Breakdown atau Down time loss. Untuk itu inventori bahan baku yang tepat menjadi sangat dibutuhkan. Inventori bahan baku yang baik dapat membantu dalam menyelesaikan Six Big Losses proses produksi, Dengan mewujudkan perangkat lunak sistem informasi inventori pergudangan yang aplikatif dan mudah di operasikan diharapkan penelitian ini dapat melengkapi sistem SAP (System, Application, Products in Data Processing) yang dipergunakan di PT.TGLC. dengan analisa menggunakan Metode ERP untuk memprediksi inventori persediaan minimum dan maximum 
gudang bahan baku. Diharapkan dapat menyelesaikan persediaan bahan baku tanpa harus menunggu bahan baku di saat bagian produksi akan mengolah untuk produksi.

Penelitian ini dilakukan dengan tujuan melengkapi sistem inventori SAP(System, Application, Products in Data Processing) yang digunakan di PT TGLC saat ini dan dengan perbaikan menggunakan Metode ERP untuk memprediksi inventori persediaan minimum dan maximum gudang suku cadang, sehingga dapat dilakukan pemantauan kebutuhan dan ketersediaan bahan baku di gudang secara realtime dan akurat, untuk kelancaran operasional perusahaan ini, perancangan atau pembuatan sistem informasi untuk memperoleh penyelesaian pengontrolan persediaan bahan baku menggunakan sistem ERP dengan tujuan megurangi breakdown yang di sebabkan oleh tidak tersedianya atau terlambatnya bahan baku yang diakibatkan oleh sistem informasi persediaan bahan baku yang tidak akurat akibat lamanya bongkar muat.

\section{TINJAUAN PUSTAKA}

Penelitian yang pernah dilakukan oleh Ade putri kinanthi di perusahaan PT. Djitoe Indonesia Tobaco sebuah perusahaan yang memproduksi Rokok kretek, dengan menggunakan metode diagram fishbone mendapatkan kesimulan bahwa factor yang mempengaruhi kelebihan stock antaralain, manusia, metode yang digunakan, keuangan erusahaan, dan matrial dendan pengendalian persediaan maka perusahaan tersebut mampu menghemat biaya samai $\mathrm{Rp} 700.000$ setia piriodenya selain dapat mengurangi biaya simpan perusahaan, mengingat harga komoditi yang naik turun. Dengan begitu system inventori persediaan sangat penting disini [Ade putri kinanthi 2016].

Fingersport RF-100 adalah type dan jenis mesin akseskontrol pintu atau absen. Alat dengan desain minimalis dan elegan tanpa kyped dan Lcd, mudah dipasang dan dioperasikan mempunyai kemampuan yang handal, dapat mengitregasikan Card rider terbaik mudah dioperasikan, mempunyai kapasitas kartu RFID hingga 30.000 card dan mampu menyimpan data transaksi hingga 50.000 record, data ini bias dihapus saat mesin penuh, Multi koneksi, dilengkapi dengan koneksi TCP/IP, RS232/RS485, sehingga banyak pilihan dalam pertukaran data dari dan ke komputer serta komunikasi dengan akses kontrol lain, USB flash disk, fitur ini sangat bermanfaat jika mesin dipasang jauh dari komputer, sehingga data dapat diambil menggunakan flash disk, Powerful software, software yang disertakan khusus didesain untuk akses kontrol, sehingga user bisa melihat data akses mesin maupun melakukan pengaturan yang terkait akses kontrol [Fingersport, Usear's guide fingersport.2016]

Inventori dengan system berbasis Clien server dengan memakai VMware 9.0.0 ([penelitian yang dilakukan di bengkel besi Rangga Jaya Bogor]. melakukan transaksi mengunakan data berbasis VMware untuk menghitung mencatat dan kegiatan administrasi lainya, Laporan yang dihasilkan hanya laporan data master, laporan transaksi dan laporan pembayaran, sehingga sistem inventori yang dibangun dapat menghitung dan mencatat secara cepat sehingga mempermudah karyawan dalam penyelesaian tugas [Adam Farooqi, 2015].

Diagram tulang ikan (fishbone) adalah metode yang biasanya digunakan untuk meningkatkan kualitas, dimetode ini penyelesainan masalah dilakukan dengan mencari sebab akibat atau cause effeck diagram. Diagram ini ditemukan oleh ilmuwan tehnik kimia Universitas Tokyo Jepang pada tahun 60-an, Bernama Dr. Kaoru Ishikawa, lahir tahun 1915 di Tokyo Jepang, Fungsi dasar diagram fishbone ini adalah untuk mengidentifikasi dan mengorganisasi penyebabpenyebab yang mungkin timbul dari suatu efek sepisifik dan kemudian memisahkan akar masalah penyebabnya, Masalah klasik yang ada didalam penghambat di industri manufaktur antara lain :

a. Keterlambatan proses produksi.

b. Tingkat defect(cacat) produksi yyang tinggi.

c. Mesin produksi yang sering mengalami trobel.

d. Output lini produksi yang tidak setabil yang berakibat tersendatnya plant produksi.

e. Produktifitas yang tidak bisa mencapai target.

f. komplain dari pelanggan yang sering dan berulang.

Untuk itulah dalam penelitian ini digunakan metode tulang ikan, sebabdan akibat yang ditimbulkan. Sebelum mengunakan diagram ini diperlukan data yang falit untuk mencari dan 
penyelesaian masalah yang ada yaitu Mengukur waktu Bongkar Muat Trucking Gudang menggunakan akses kontrol card rider. [www.dictio.id/t/]

\section{Penyajian Data dan Layout}

Proses penyusunan atau pelaksanaan penelitian dilakukan beberaa tahaan yang dilakukan seprti tergambar dalam kerangka pemikiran pelaksanaan tahapan-tahapan penelitian sesuai dengan kerangka pemikiran meliputi :

a. Menganalisa dan mempelajari Sistem yang sudah digunakan saat ini (Sistem SAP).

b. Mencari dan menemukan gagasan sebagai dasar dari perancangan penelitian proyek sistem aplikasi Metode Card rider akses kontrol mengunakan kartu RFID.

c. Melakukan penelitian aplikasi yang dipergunakan dan membandingkan sistem yang ada dengan sistem kontrol dengan aplikasi pencatatan waktu untuk perbaikan sistem yang akan dirancang.

d. Pengadaan bahan penelitian.

e. Uji coba seluruh sistem yang sudah dibuat.

f. Analisis sistem.

Aplikasi Metode Card rider akses kontrol mengunakan kartu RFID ini terdiri dari beberapa menu. Untuk memudahkan para pengguna dalam mengoperasikan aplikasi ini, maka akan dijelaskan alur standar penggunaan aplikasi. Tujuannya untuk membantu memahami cara kerja dari aplikasi ini. Alur penggunaan aplikasi dapat digambarkan sebagai berikut :

\section{Mendaftarkan kedatangan truck pengangkut di mesin}

Truck pengangkut yang akan menggunakan mesin absensi harus diregistrasikan atau didaftarkan terlebih dahulu di mesin agar dapat dikenali oleh mesin. Registrasi dapat berupa registrasi jari sipelapor(Kenek/supir), password maupun kartu tergantung jenis mesin dan kebutuhan kita.

\section{Menambahkan mesin-mesin ke aplikasi}

Setelah instalasi aplikasi, ada tiga mesin yang langsung terdaftar dengan tipe koneksi yang berbeda. Jika Anda menggunakan lebih dari tiga mesin, maka semua mesin tersebut harus ditambahkan dalam aplikasi. Jika Anda menggunakan mesin kurang dari tiga, kita hanya tinggal menyesuaikan parameter komunikasi yang sesuai dengan mesin kita.

\section{Download truck pengangkut dan teping kartu ke dalam aplikasi}

Setelah truck pengangkut diregistrasi pada mesin, maka data dan teping kartu pelapor(kenek/supir) tersebut harus didownload ke dalam aplikasi. Langkah ini untuk mengambil data pada kartu pelapot (kenek/supir) sekaligus mengamankan data kartu yang tersimpan di dalam mesin ke dalam aplikasi. Jika terjadi kerusakan mesin di kemudian hari, maka data dan teping kartu pelapot(kenek/supir) masih tersimpan di dalam database aplikasi dan dapat diupload balik ke mesin. Data pelapot [kenek/supir] yang didownload secara otomatis akan mengisi daftar antrian pelapot(kenek/supir) pada menu antian.

\section{METODE}

PT TGLC adalah perusahaan yang belum lama berdiri, untuk kelancaran produksi dan pemeliharaan mesin-mesin, dibutuhkan kecepatan suplai bahan baku untuk suplai yang selalu tersedia didalam gudang penyimpanan ke rea proses produksi

Implementasi Metode Card rider akses kontrol mengunakan kartu RFID, sebelum dipasangkan dari skema tersebut yang dahulu ada dibutuhkan beberapa data seperti historikal pengeluaran serta waktu tunggu (lead time) yaitu lamanya waktu dimulai dari bongkar bahan baku untuk suplai yang akan di produksi yang sudah mencapai batas minimum persediaan hingga 
datang untuk penambahan persediaan bahan untuk produksi, dalam mengelola inventori gudang dapat dilakukan secara manual dengan cara mencatat setiap barang yang masuk dan keluar pada sebuah buku [IDTECHEX, 2006], cara ini mempunyai kelemahan karena banyak melibatkan unsur manusia yang umumnya sering lupa. Sebuah sistem informasi inventori pergudangan berbasis web dibuat untuk mengatasi kelemahan-kelemahan yang ada pada sistem manual. Sistem ini mempunyai banyak kelebihan karena informasi mengenai ketersediaan barang disimpan dalam komputer dan internet yang dapat diakses di setiap tempat. apabila pencatatn masih mengunakan manual akan mudah terjadi kesalahan terutama ketepan waktu bangkar muat bahan, untuk itulah diperlukan aplikasi pencatatan kapan waktu bongkar dimulai dan kapan waktu bongkar atau pengiriman selesai. Gambar sekema dibawah adalah flowchart Bongkar muat Gudang yang dipantau menggunakan Aplikasi, Aplikasi ini terdiri dari beberapa menu. Untuk memudahkan para pengguna dalam mengoperasikan aplikasi Metode Card rider akses kontrol mengunakan kartu RFID ini, maka akan dijelaskan alur standar penggunaan aplikasi. Tujuannya untuk membantu memahami cara kerja dari aplikasi Metode Card rider akses kontrol mengunakan kartu RFID ini.

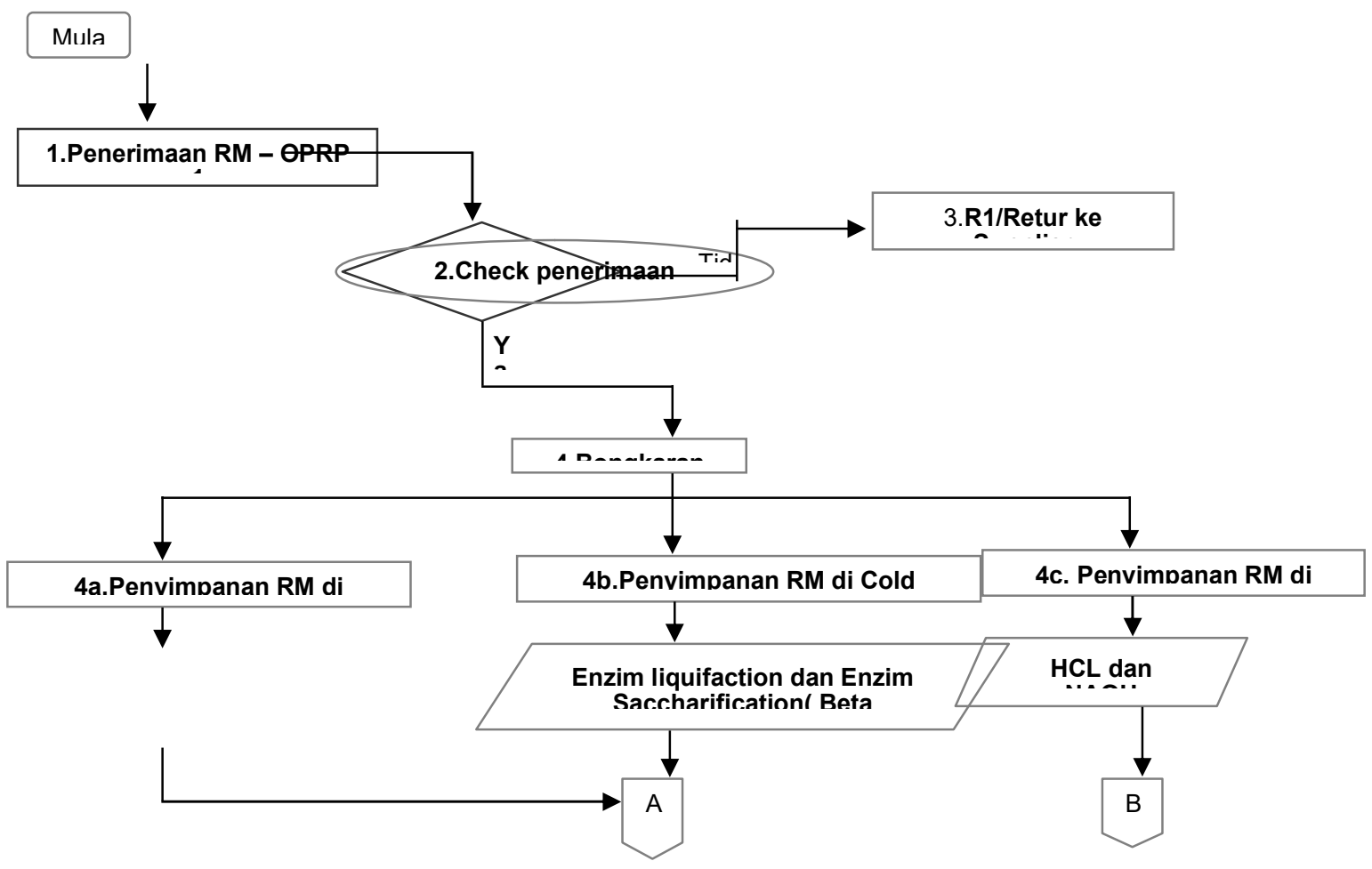

Gambar 1. Flow Proses Penerimaan Barang Di Gudang External.

\section{HASIL DAN RENCANA PEMBAHASAN}

Untuk saat ini perusahaan tempat penelitian sudah menerapkan Aplikasi SAP(System Application Products in data Processing) aplikasi, untuk meng akses sistm ini menggunakan front-end atau SAP GUI (Graphical User Interface), hanya karyaewan yang bertugas data mengoperansikan sisiem. Sehingga pencatatan kedatangan kendaraan pengangkut masih manual kemudian di imputkan kedalam data komputer satu persatu, sehingga menghambat bongkar muat, selain kendala pencatatan Dengan tampilan seperti dibawah inilah bongkar muat barang terkendala.

Dengan adanya Gambaran flow proses dalam penaganan kedatangan dan bongkar muat gudang akan dilakukan rencana perbaikan dengan time table sebagai beikut: 


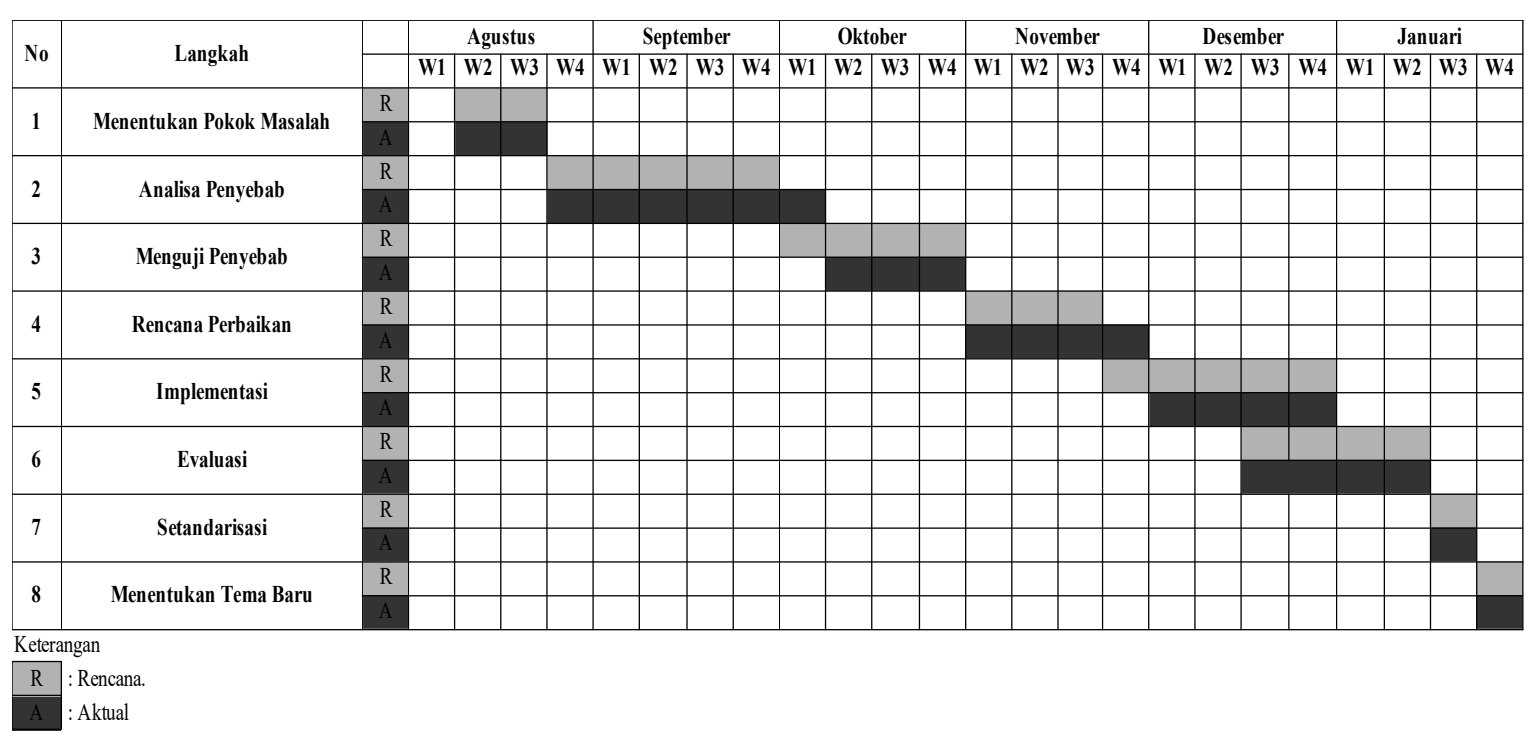

Gambar 2. Time table Proses perbaikan Penerimaan Barang Di Gudang.

Setelah analisa dan penentuan prototype metode Metode Card rider akses kontrol mengunakan kartu RFID, harus disesuaikan juga Hardware dan software yang saling mendukung. Supaya tidak terjadi permasalahan baik pada system, peralatan maupun penguna setelah selesai system dibuat dan di pasang alat dan sisitem.
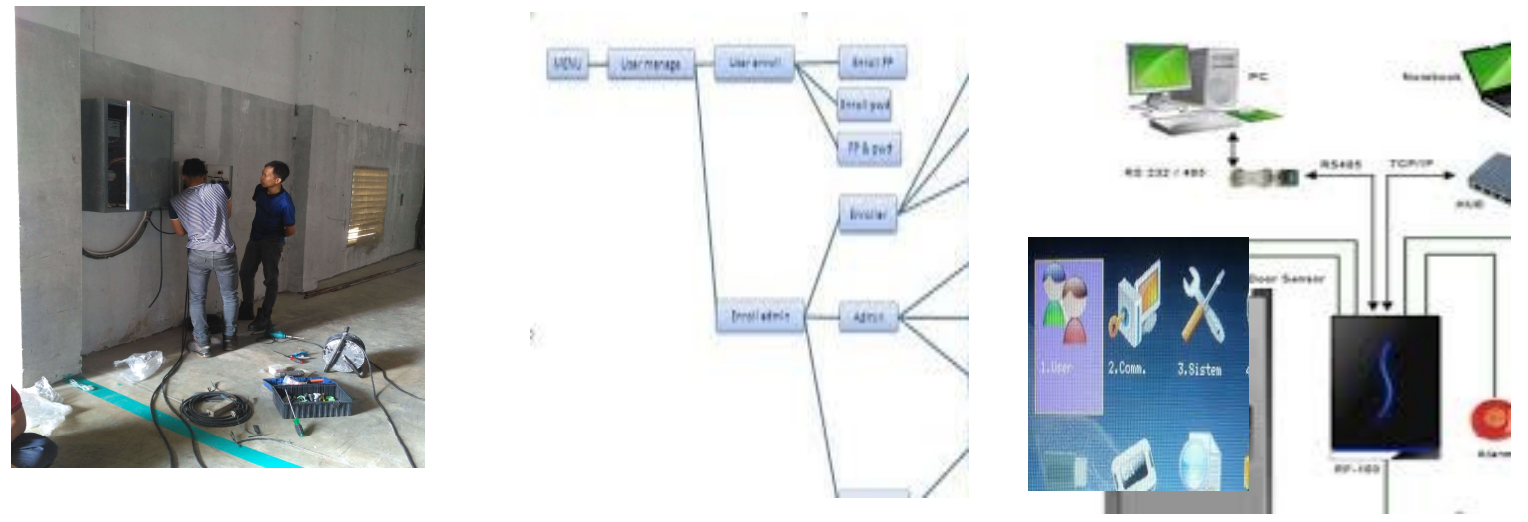

Gambar 3. Proses instalasi mesin akseskontrol mengitregasikan Card rider.

Setelah instalasi selesai dan komputer siap di pergunakan, untuk pengambilan data dari alat dengan proses sebagai berikut :

\section{Mulai}

- Saat komputer nyala, aktifkan aplikasi : Pada saat komputer startup secara otomatis aplikasi ini juga langsung dijalankan.

- Ketika aplikasi aktif, aktifkan pemantauan : Pada saat aplikasi dijalankan, maka secara otomatis aplikasi akan berubah terkoneksi dengan mesin.

\section{Download Data Presensi}


- Download semua data : Pada saat download data presensi, maka seluruh data di mesin akan didownload.

- Download hanya data baru saja : Pada saat download data presensi, maka hanya data terbaru yang akan didownload.

- Hapus data di mesin setelah download : Setelah download berhasil, maka data di mesin akan dihapus.

- Informasikan perkembangan download data : Pada saat download, akan tampil progress bar yang menunjukkan progress dari download.

- Simpan ke file setelah download : Setelah download data selesai, maka data akan disimpan ke dalam file pada tempat yang ditentukan dengan format yang ditentukan pula.

\begin{tabular}{|c|l|c|c|} 
NO & \multicolumn{1}{|c|}{ MASALAH } & FAKTOR & DIUSULKAN \\
\hline 1 & Proses bongkar manual & Metode & Jamal \\
\hline 2 & $\begin{array}{l}\text { Matrial tersangkut di dalam Truck pada saat Penarikan } \\
\text { lbongkar }\end{array}$ & Matrial & Welman \\
\hline 3 & Forklif sering rusak pada bagian hose hidrolik & Mesin & Ngatino \\
\hline & $\begin{array}{l}\text { Area untuk proses penarikan matriyal dari dalam truck } \\
\text { panjang }\end{array}$ & Lingkungan & Wawan \\
\hline
\end{tabular}

Dengan mempelajari data2 diatas ditargetkan perbaikan sistem dengan target penurunan waktu bongkar muat seperti metrik tardet di bawah. Dari lamanya 1 truck 40 menit dalam membongkar kita targetkan 25 menit, sesuai dengan pencatatan oleh sistem Card rider komputer :

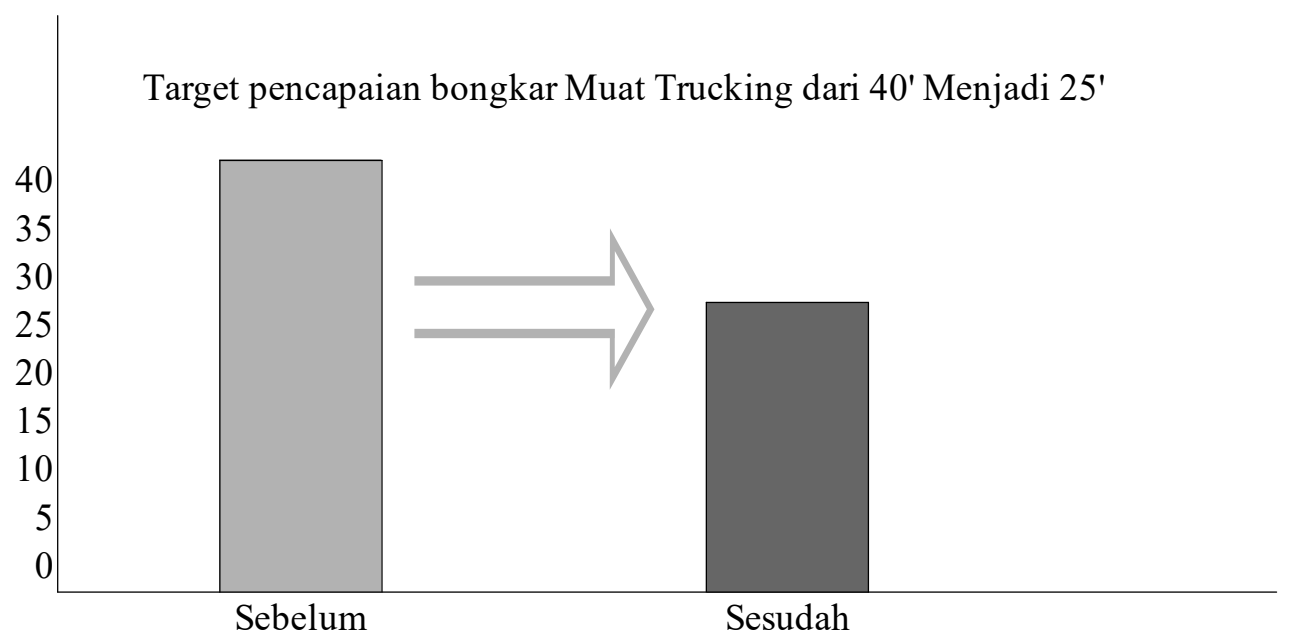

Gambar 4. Grafik waktu bongkar Penerimaan Barang Di Gudang.

Dengan gambaran dan target waktu seperti pada gambar diatas dilakukan strategi-setrategi seperti rencana berikut : 


\begin{tabular}{|c|c|c|c|c|c|c|}
\hline \multicolumn{7}{|c|}{ ANALISA SEBAB AKIBAT } \\
\hline NO & MASALAH & WHY.1 & WHY.2 & WHY.3 & WHY.4 & WHY.5 \\
\hline 1 & \multirow{4}{*}{$\begin{array}{l}\text { BONGKAR MUAT } \\
\text { LAMA }\end{array}$} & Proses Bongkar muat & $\begin{array}{lll}\text { Belom dipasang } & \text { Loding } \\
\text { Ram } & & \\
\end{array}$ & Belom di Order & & \\
\hline 2 & & $\begin{array}{l}\text { Matrial tersangkut saat proses } \\
\text { penarikan/Bongkar }\end{array}$ & $\begin{array}{l}\text { Susunsn matrial dalam Truck } \\
\text { tidak rapi }\end{array}$ & $\begin{array}{l}\text { Susunsn barang } \\
\text { Roboh }\end{array}$ & $\begin{array}{l}\text { Guncangan Truck saat } \\
\text { dalam perjalanan }\end{array}$ & \\
\hline 3 & & $\begin{array}{l}\text { Forklif sering rusak pada bagian } \\
\text { hose hidrolik }\end{array}$ & \begin{tabular}{|lrr} 
Forklif & dipergunakan \\
menarik & bsrsng & saat \\
bongksrsn & &
\end{tabular} & $\begin{array}{lr}\text { Forklif } & \text { tidak } \\
\text { masuk } & \text { bedalam } \\
\text { kontainer } & \end{array}$ & $\begin{array}{l}\text { Belum dipasang Loding } \\
\text { Ram }\end{array}$ & $\begin{array}{l}\text { Belum } \\
\text { Order }\end{array}$ \\
\hline 4 & & $\begin{array}{l}\text { Area untuk proses penarikan } \\
\text { matriyal dari dalam truck panjang }\end{array}$ & $\begin{array}{l}\text { Karena ukuran kontainer } 4 \\
\text { feets semua }\end{array}$ & & & \\
\hline
\end{tabular}

Analisa sebab akibat bongkar Penerimaan Barang Di Gudang.

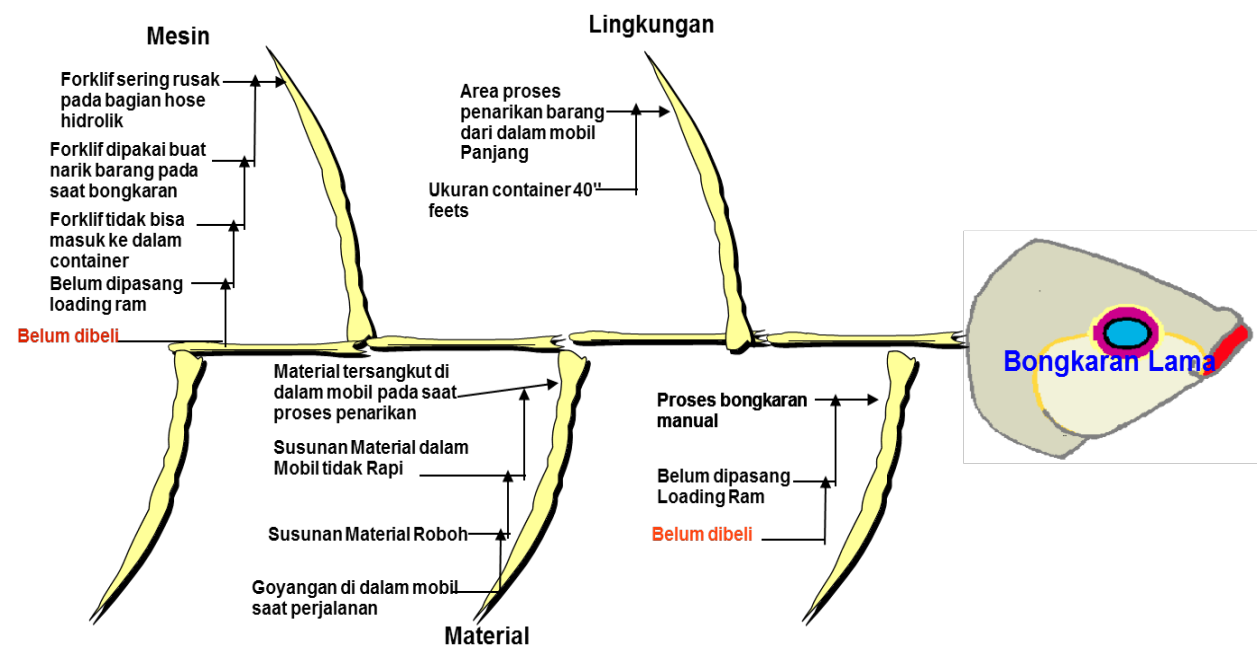

Gambar 5. Analisa sebab akibat bongkar Penerimaan Barang Di Gudang memakai Fice bond.

\section{Pembahasan Data II}

\begin{tabular}{|c|c|c|c|c|c|}
\hline \multicolumn{6}{|c|}{ Rata-rata Waktu Bongkar dengan Loading Ram } \\
\hline NO & Tanggal & NAMA MATERIAL & JUMLAH TRUCK & UKURAN TRUCK & RATA-RATA WAKTU \\
\hline 1 & 30 April 2019 & Corn Starch Jilin $830 \mathrm{Kg}$ & 10 & Container 40 feet & 24 \\
\hline 2 & 1 Mei 2019 & Corn Starch Jilin $830 \mathrm{Kg}$ & 9 & Container 40 feet & 24 \\
\hline 3 & 2 Mei 2019 & Corn Starch Jilin $830 \mathrm{Kg}$ & 9 & Container 40 feet & 24 \\
\hline 4 & 3 Mei 2019 & Corn Starch Jilin $830 \mathrm{Kg}$ & 18 & Container 40 feet & 22 \\
\hline 5 & 4 Mei 2019 & Corn Starch Jilin $830 \mathrm{Kg}$ & 14 & Container 40 feet & 22 \\
\hline 6 & 9 Mei 2019 & Corn Starch Jilin $830 \mathrm{Kg}$ & 1 & Container 40 feet & 25 \\
\hline 7 & 22 Juni 2019 & Corn Starch Jilin $830 \mathrm{Kg}$ & 16 & Container 40 feet & 23 \\
\hline 8 & 24 Juni 2019 & Corn Starch Jilin $830 \mathrm{Kg}$ & 5 & Container 40 feet & 17 \\
\hline 9 & 27 Juni 2019 & Corn Starch Jilin $830 \mathrm{Kg}$ & 11 & Container 40 feet & 23 \\
\hline 10 & 28 Juni 2019 & Corn Starch Jilin $830 \mathrm{Kg}$ & 15 & Container 40 feet & 21 \\
\hline \multicolumn{5}{|c|}{ Total Rata-rata Waktu Bongkar : } & 23 \\
\hline
\end{tabular}

Gambar 6. Waktu Bongkaran setelah dilakukan perbaikan menggunakan Loading Ram Grafik di atas menunjukan Bahwa setelah menggunakanLoad ing Ram waktu bongkaran bisa dicapai dalam waktu 23 menit. 
Berdasarkan pengamatan yang ada dilapangan level dock memiliki pengaruh signifikan terkait dengan waktu bongkaran, karena forklift bisa langsung handling pallet sebagai alas jumbo bag diatas Truck, dan menyusun di gudang GTCK

\section{KESIMPULAN}

Dari Hasil pengamatan dan penelitian yang telah dilakukan mendapatkan simpulan bahwa personil bagian gudang di PT TGLC dapat melakukan control loding bongkar muat barang secara Cakap, Namun kurangnya dukungan alat bantu kerja yang baik dan terintregrasi sehingga terjadinya hambatan, Metode ERP[Enterprise Resource Planning] atau Metode Card rider akses kontrol mengunakan kartu RFID alat pencatat data yang terintregrasi membantu permasalahan yang ada karena metode tersebut, data mengintegrasikan banyak informasi yang saling terkaitan. Terutama informasi dari lapangan apa yang dibutuhkan dalam perbaikan sehingga segera diketahui dimana hambatan itu terjadi terutama masalah hambatan inventori persediaan bahan baku. Metode ERP dan Metode Card rider akses kontrol mengunakan kartu RFID akan membantu memberikan informasi, komunikasi, kordinasi antar bagian terkait, Metode konsep Card rider akses kontrol mengunakan kartu RFID dengan sistem ERP(Enterprise Resource Planning) dapat di jalankan di TGLC dengan baik bila didukung dengan jaringan perangkat yang mendukung, sehingga Metode Card rider akses kontrol mengunakan kartu RFID dan ERP untuk memprediksi inventori persediaan minimum dan maximum gudang bahan baku akan sangat membantu analisa dimana ada hambatan karena tercatat secara tepat pekerjaan di perusahaan ini.

\section{UCAPAN TERIMA KASIH}

Puji syukur Penulis ucapkan Kepada Allah SWT, karena atas berkat dan rahmat-Nya, Penulis dapat menyelesaikan Laporan penelitian ini. Oleh karena itu Penulis mengucapkan terimakasih kepada :

1. Rekan-rekan Kerja serta Mahasiswa Fakultas Teknik Informatika yang telah banyak mendukung penulis dalam menyelesaikan Laporan ini.

2. Orang tua dan keluarga Penulis yang telah memberikan dukungan material dan moral.

3. Bapak Dr. Ir Sewaka M.M selaku ketuajurusan program studi Teknik Informatika Universitas Pamulang.

4. Semua Pihak yang terlibat dan tidak penulis sebutkan satu persatu.

Penulis berharap Tuhan Yang Maha Esa berkenan membalas segala kebaikan semua pihak yang telah membantu. Semoga Laporan ini membawa manfaat bagi pengembangan ilmu pengetahuan.

\section{DAFTAR PUSTAKA}

[1] IDTECHEX, REFD Forecasts, Players And Opportunities 2006, Available: http//www.idtechex.com/products/en/articles/00000169.asp.

[2] Fingersport, User's guide, www.fingersport.com, 2016.

[3] Yasuhiro Monden, "Sistem Produksi Toyota, Seri Manejemen Operasi No. 7 PPM dengan Yayasan Toyota \& Astra” ISBN 979-442-029-8. Desember 2000.

[4] Adam farooqi, "Sistem Inventory control berbasis client server dengan menggunakan Vmware tools", ISSN 1979-8911 Volume IX No2, 21. 2017.

[5] Ade Putri Kinanthi, Analisis Pengendalian Persediaan Bahan Baku Menggunakan Metode Min-Max, [Jurnal erfoma, 2006].

[6] "Apa-yang-dimaksud-dengan-diagram-tulang-ikan", www.dictio.id/t/ 